\title{
PENGEMBANGAN GAME KUIS INTERAKTIF SEBAGAI INSTRUMEN EVALUASI FORMATIF PADA MATA KULIAH TEORI MUSIK
}

\author{
Dini Ardiningsih * \\ Sekolah Tinggi Musik Bandung, Jl. Lamping No. 16, Jawa Barat, Indonesia 40161 \\ * Corresponding Author. Email: dinipatria@gmail.com \\ Received: 2 January 2018; Revised: 30 April 2019; Accepted: 28 June 2019
}

\begin{abstract}
Abstrak
Penelitian ini bertujuan untuk menghasilkan sebuah game kuis interaktif sebagai instrumen evaluasi formatif pada mata kuliah teori musik dengan mengadaptasi sebuah game kuis The Impossible Quiz. Game kuis berisi pertanyaan dengan materi teori musik yang dilengkapi dengan ear training. Metode penelitian yang digunakan adalah metode Research and Development model ADDIE yaitu Analysis (analisis), Design (desain), Development (pengembangan), Implementation (implementasi) dan Evaluation (evaluasi). Penelitian dilakukan di Sekolah Tinggi Musik Bandung (STiMB). Kelayakan produk berdasarkan penilaian ahli materi, ahli media dan responden mahasiswa STiMB. Penilaian berupa lembar evaluasi yang meliputi empat aspek yaitu aspek materi, aspek pembelajaran, aspek tampilan dan aspek pemrograman. Secara keseluruhan rerata presentasi penilaian yaitu (1) aspek pembelajaran sebesar 79,67\%, (2) aspek materi sebesar 87,81\%, (3) aspek pemrograman sebesar 81,87\%, dan (4) aspek tampilan game sebesar $85,15 \%$. Dengan demikian dapat disimpulkan bahwa rerata penilaian di atas $80 \%$ yang berarti game kuis interaktif sangat layak dijadikan instrumen evaluasi formatif pada mata kuliah teori musik.
\end{abstract}

Kata kunci: Kuis permainan, the impossible quiz, interaktif, teori musik, ADDIE

\section{DEVELOPING INTERACTIVE QUIZ GAME AS FORMTIVE EVALUATION INSTRUMENT OF MUSIC THEORY SUBJECT}

\begin{abstract}
This research was aim to produce an interactive game quiz as a instrument for formative evaluation of subject Music Theory adapted from The Impossible Quiz. The game consist of Music Theory learning materials and be equipped with ear training materials. This research was conducted by Research \& Development method with ADDIE model which is Analysis, Design, Development, Implementation and Evaluation. All of research process were held at Sekolah Tinggi Musik Bandung (STiMB). Properness of the reasearch was evaluated by Music Theory expert, multimedia expert and students of Sekolah Tinggi Musik Bandung. Four aspects were have been evaluated by the respondents includes interface aspect, contents, learning materials and programming aspect. In average, learning materials got precentage of $79,67 \%$, contents $87,81 \%$, programming $81,87 \%$, and interface aspect $85,15 \%$. Those result conduct conclusion of $80 \%$ rating of this evaluation which means the game quiz are appropriate to become a instrument for formative evaluation on Music Theory subject.
\end{abstract}

Keywords: Quiz game, the impossible quiz, interactive, music theory, ADDIE

http://dx.doi.org/10.21831/jitp.v6.1.17725 


\section{Pendahuluan}

Game atau permainan dalam bentuk apapun mempunyai daya tarik tersendiri bagi pemainnya. Umumnya game berfungsi sebagai hiburan, biasanya berisi aturan dan tantangan dengan tujuan pencapaian skor atau level yang menjadi kepuasan bagi pemainnya. Game adalah an activity that you do for fun that has rules, and that you can win or lose (Rundell, 2007) yang dapat diartikan sebagai sebuah aktivitas yang dilakukan untuk bersenang-senang yang memiliki aturan sehingga ada yang kalah dan ada yang menang. Selain menarik dan menyenangkan, alasan seseorang bermain game antara lain untuk mengisi waktu luang, karena terpengaruh lingkungan, ingin menjadi pemenang, atau sudah kecanduan.

Karena sifatnya yang menarik dan menghibur, saat ini game juga dikembangkan dalam dunia pendidikan dimana fungsinya adalah sebagai media belajar yang dapat menghasilkan pengalaman pembelajaran yang menyenangkan. Menurut Luca Botturi dan Christian Loh (Setiawan, 2015, p. xii) game dalam pembelajaran dapat digunakan untuk menjelaskan konsep dan memperkuat pembelajaran. Berbeda dengan game untuk hiburan, game untuk pembelajaran mempunyai tujuan untuk mencapaian pembelajaran tertentu. Selain itu, game juga dapat dimanfaatkan sebagai media untuk melatih kemampuan siswa dalam menyelesaikan masalah, menemu-kan solusi, berpikir cepat dan berkompetisi.

Fungsi game dalam pembelajaran selain untuk mencapai tujuan pembelajaran, juga dapat digunakan sebagai instrumen evaluasi pembelajaran, yaitu untuk mengetahui capaian dari tujuan pembelajaran. Menurut Cross (dalam Sukardi, 2012, p. 1) Evaluation is a process which determines the extent to which objectives have been achived. Menurut Sukardi (2012, p. 4) tujuan evaluasi adalah: (1) Sebagai alat guna mengetahui apakah peserta didik telah menguasai pengetahuan, nilai-nilai dan keterampilan yang telah diberikan oleh seorang guru; (2) Untuk mengetahui aspek-aspek kelemahan peserta didik dalam melakukan kegiatan belajar; (3) Mengetahui tingkat ketercapaian siswa dalam kegiatan belajar; (4) Sebagai sarana umpan balik bagi seorang guru, yang bersumber dari siswa; (5) Sebagai alat untuk mengetahui perkembangan belajar siswa; (6) Sebagai materi utama laporan hasil belajar kepada orangtua siswa.

Alasan mengapa evaluasi harus dilakukan, menurut Reece dan Walker (dalam Aunurrahman, 2014, p. 209), yaitu: (1) Memperkuat kegiatan belajar; (2) Menguji pemahaman dan kemampuan siswa; (3) Memastikan pengetahuan prasyarat yang sesuai; (4) Mendukung terlaksananya kegiatan pembelajaran; (5) Memotivasi siswa; (6) Memberi umpan balik bagi siswa; (7) Memberi umpan balik bagi guru; (8) Memelihara standar mutu; (9) Mencapai kemajuan proses dan hasil belajar; (10) Memprediksi kinerja pembelajaran selanjutnya; (11) Menilai kualitas belajar.

Melihat pentingnya evaluasi dalam pembelajaran sebagai proses untuk mendapatkan umpan balik guna mencapai kemajuan proses dan hasil belajar, sudah seharusnya kegiatan evaluasi dilakukan oleh seorang pengajar di setiap akhir pokok bahasan, yaitu dengan melakukan evaluasi formatif. Evaluasi formatif Menurut Winkel (dalam Aunurrahman, 2014, p.221) adalah penggunaan tes-tes selama proses pembelajaran yang masih berlangsung, agar siswa dan guru memperoleh informasi (feedback) mengenai kemajuan yang telah dicapai.

Inti dari manfaat evaluasi formatif bagi siswa, menurut Arikunto (2015, p. 50) adalah: (1) Digunakan untuk mengetahui apakah siswa sudah menguasai materi program secara menyeluruh; (2) Merupakan penguatan (reinforcement) bagi siswa; (3) Usaha perbaikan; (4) Sebagai diagnosa. Melalui evaluasi formatif, selain siswa dapat menguasai materi yang dipelajari secara menyeluruh, juga dapat menjadi penguatan, yaitu merasa sudah memiliki pengetahuan yang benar dan termotivasi untuk mempertahankan bahkan meningkatkan hasil yang 
telah diperoleh. Selain itu, akan terjadi usaha perbaikan setelah siswa mengetahui kelemahan dan materi yang belum dikuasai serta dapat mengetahui lebih jelas bagian mana dari materi pelajaran yang masih dianggap sulit.

Pentingnya evaluasi formatif dalam pembelajaran tentu harus didukung dengan instrumen evaluasi formatif yang tepat. Instrumen atau alat adalah sesuatu yang dapat digunakan untuk mempermudah seseorang dalam melaksanakan tugas atau mencapai tujuan secara lebih efektif dan efisien (Arikunto, 2015, p. 40). Sementara evaluasi formatif atau tes formatif merupakan salah satu dari teknik evaluasi yaitu teknik tes yang biasanya diberikan pada akhir setiap program. Dengan demikian instrumen evaluasi formatif dapat diartikan sebagai alat tes yang digunakan di setiap akhir program untuk mengetahui hasil dari yang dievaluasi baik itu siswa, guru maupun program.

Bentuk tes dalam pembelajaran dibedakan dalam dua bentuk yaitu tes subjektif dan tes objektif. Tes subjektif umumnya dalam bentuk uraian, sementara tes objektif terdiri dari bentuk benar salah, pilihan ganda, menjodohkan dan isian. Bentuk tes tentunya harus disesuaikan dengan tujuan pemberian tes, mengingat tes berfungsi untuk mengevaluasi. Selain bentuk tes, hal yang perlu diperhatikan adalah menyusun soal tes, yang mencakup bentuk pertanyaan dan jawaban, jumlah pertanyaan dan waktu yang dibutuhkan siswa untuk menyelesaikan tes tersebut.

Salah satu instrumen evaluasi formatif yang sering dilakukan di kelas adalah dalam bentuk ulangan atau kuis baik secara tertulis maupun lisan. Pada dasarnya keduanya berisi pertanyaan-pertanyaan pendek yang berhubungan dengan materi yang telah dipelajari. Kuis lisan khususnya digunakan untuk mengukur ranah kognitif yang ditekankan pada aspek ingatan. Pertanyaan ingatan biasa digunakan untuk mengukur penguasaan materi yang berupa fakta, istilah, definisi, klarifikasi atau kategori, urutan maupan kriteria (Arikunto, 2015, p. 169). Pemberian kuis lisan di setiap akhir pokok bahasan dilakukan untuk memotivasi siswa dalam melatih dan mengukur kemampuannya dengan cara berpikir cepat dalam bentuk kompetisi. Kuis sebagai instrumen evaluasi formatif, selain dalam bentuk tertulis dan lisan, dapat dikembangkan menjadi kuis interaktif. Kuis interaktif merupakan aplikasi berbasis komputer dalam betuk multimedia. Untuk dapat menghasilkan sebuah kuis interaktif yang menarik, diperlukan observasi terhadap beberapa jenis kuis interaktif, salah satu caranya adalah dengan mengadaptasi kuis interaktif yang populer. Dengan mengadaptasi kuis interaktif yang populer, selain dapat menjadi daya tarik bagi pengguna juga dapat memudahkan pengguna dalam memainkannya karena sudah mengetahui aturan mainnya.

Salah satu game kuis interaktif yang cukup populer adalah The Impossible Quiz yang dikembangkan oleh Glenn Rhodes yang lebih dikenal dengan nama Splapp-medo. Game tersebut dirilis pada tanggal 20 Februari 2007 di Newgrounds dan deviantArt. Popularitas game kuis ini telah menginspirasi penggemarnya untuk membuat game serupa, salah satunya adalah Parampaa yang dibuat oleh orang Indonesia bernama Bisri Masova. The Impossible Quiz dikenal sebagai game dengan banyak jebakan, tetapi tidak kehilangan daya tarik para pemainnya, sehingga seringkali disebut sebagai permainan yang "menyebalkan" tetapi membuat penasaran pemainnya. The Impossible Quiz berisi pertanyaan-pertanyaan sederhana namun jawabannya tidak sesederhana pertanyaannya. Konsentrasi dan usaha mengingat menjadi tantangan dalam memainkan game ini.

Daya tarik game kuis The Impossible Quiz telah menarik perhatian penulis, sehingga terinspirasi untuk mencoba geme kuis tersebut, kemudian menelitinya untuk dikembangkan menjadi instrumen evaluasi formatif pada mata kuliah teori musik di Sekolah Tinggi Musik Bandung (STiMB). Teori Musik merupakan studi tentang struktur musik yang mencakup analisis elemen dasar musik mulai dari melodi, har- 
moni, irama, bentuk, tekstur dan fungsi dari masing-masing elemen. Sama halnya dengan bidang ilmu lainnya, istilah teori mengikuti praktek juga berlaku dalam musik. Tujuan Teori Dasar Musik adalah untuk memperkenalkan konsep-konsep umum dan terminologi yang akan berguna baik dalam memainkan maupun menganalisis musik (Jones, 1974, p. xv).

Mata kuliah teori musik di STiMB merupakan mata kuliah dasar yang menjadi prasyarat untuk mata kuliah lain di semester selanjutnya, salah satunya adalah mata kuliah harmoni. Namun banyaknya materi yang harus dipelajari, membuat mata kuliah teori musik menjadi mata kuliah paling sulit di semester satu. Hal ini disebabkan karena umumnya mahasiswa yang masuk STiMB adalah lulusan Sekolah Menengah Atas (SMA) yang sama sekali belum pernah mempelajari teori musik sebelumnya. Adapun upaya yang dilakukan dosen untuk membantu mahasiswa dalam menguasai materi salah satunya adalah memberikan kuis dan worksheet di setiap akhir pokok bahasan, mamun hal tersebut terkadang membuat mahasiswa merasa bosan karena terlalu sering dilakukan dengan cara yang sama.

Berdasarkan uraian tersebut, penulis tertarik untuk melakukan pengembangan instrumen evaluasi formatif untuk mata kuliah teori musik dalam bentuk tes objektif untuk mengukur ranah kognitif yang lebih menekankan pada aspek ingatan. Pengembangan tersebut berupa perancangan game kuis interaktif berbasis komputer dalam bentuk multimedia dengan cara mengadaptasi game kuis The Impossible Quiz yang berisi pertanyaan dengan konten materi mata kuliah teori musik. Adapun konten materi yang digunakan dalam penelitian ini difokuskan pada materi teori musik semester satu. Game kuis tersebut diharapkan dapat memberikan efek refresh sehingga dapat menciptakan suasana belajar yang menyenangkan, serta dapat menjadi media berlatih mahasiswa untuk mengingat materi yang telah dipelajari di luar jam perkuliahan.

\section{Metode}

Tujuan penelitian ini adalah mengembangkan sebuah produk game kuis interaktif sebagai instrumen evaluasi formatif pada mata kuliah teori musik. Penelitian dilakukan di Sekolah Tinggi Musik Bandung dengan subjek penelitaian mahasiswa semester dua (angkatan 2014/2015). Adapun metode penelitian yang digunakan adalah Research and Development (RED) model ADDIE. RED dalam pendidikan menurut Gall, Borg, dan Gall (2003, p. 569) merupakan sebuah model pengembangan berbasis industri dengan tujuan untuk mendesain sebuah produk baru lengkap dengan prosedur operasinya yang diuji terlebih dahulu secara sistematis kemudian dievaluasi dan diperbaiki kembali hingga menemukan kriteria-kriteria yang lebih spesifik tentang efektivitas produk, kualitas produk atau persamaan standar umum produk.

Adapun fungsi konsep ADDIE yaitu menjadi pedoman dalam membangun perangkat dan infrastruktur program pelatihan yang efektif, dinamis dan mendukung kinerja pelatihan itu sendiri. Fungsi ADDIE menurut Branch $(2009, \mathrm{p}, 2)$ adalah:

ADDIE is an acronym for Analyze, Design, Develop, Implement, and Evaluate. ADDIE is a product development concept. The ADDIE concept is being applied here for constructing performance based learning. The educational philosophy for this application of ADDIE is that intentional learning should be student centered, innovative, authentic, and inspirational. The concept of systematic product development has existed since the formation of social communities.

Pada dasarnya ADDIE merupakan sebuah konsep pengembangan produk untuk menyusun model pendekatan pembelajaran yang mengutamakan kemampuan siswa untuk melakukan atau mengaplikasikan pengetahuan yang telah diperoleh. Filosofi dari penerapan ADDIE adalah proses belajar harus fokus terhadap siswa, harus inovatif, otentik atau orisinil dan inspiratif. Konsep pengembangan pro- 
duk yang sistematis harus sudah ada sejak subjek komunitas sosial dibentuk.

Mengingat pengembangan dalam penelitian ini menggunakan model ADDIE, yang merupakan model generik dari $R \mathcal{E} D$, maka tidak semua tahapan dalam $R \mathcal{E} D$ dilakukan dalam penelitian ini. Dengan menggunakan model ADDIE tahapan penelitian disederhanakan menjadi lima tahapan, yaitu tahap analysis, design, development, implementation, dan evaluation. Hal ini dilakukan karena metode penelitian $R \mathcal{E} D$ pada dasarnya berbentuk siklus yang dalam prosesnya memerlukan waktu lama. Selain itu, produk akhir dari $R \mathcal{E} D$ merupakan produk massal yang memerlukan tahap uji coba menyeluruh dengan melibatkan banyak subjek uji coba setra beberapa lokasi uji coba.



Gambar 1. The ADDIE concept (Branch, 2009, p. 2)

Penggunaan metode $R \mathcal{E} D$ dengan model ADDIE dalam penelitian ini dinilai tepat karena (1) Fokus penelitian ini adalah merancang dan mengembangkan sebuah produk game kuis interaktif sebagai instrumen evaluasi formatif pada mata kuliah teori musik; (2) Kelayakan produk game kuis interaktif berdasarkan penilaian para ahli dan responden; (3) Uji coba merupakan uji coba terbatas yang hanya dilakukan di lingkungan STiMB dengan subjek penelitian kurang dari 50 orang.

Berdasarkan konsep ADDIE, perancangan game kuis interaktif terdiri dari lima proses, yaitu analysis, design, development, implementation, dan evaluation. (1) Analysis mencakup analisis game kuis The Impossible Quiz, pengguna, instrumen evaluasi forma- tif di STiMB dan materi teori musik semester satu di STiMB; (2) Design mencakup jadwal perancangan, pembentukan tim, dan perancangan game kuis; (3) Development dalam penelitian ini merupakan tahap merealisasikan tahap desain; (4) Implementation terdiri dari tiga tahap, yaitu implementasi tahap satu untuk mengetahui pemasalahan yang muncul, implementasi tahap dua untuk memastikan kualitas setelah dilakukan revisi dan implementasi tahap tiga untuk mengetahui respon pengguna; (5) Evaluation dalam penelitian ini berdasarkan penilaian dari ahli materi dan ahli media serta penilaian dari responden mahasiswa STiMB.

Teknik pengumpulan data meliputi observasi, wawancara, dan angket. Observasi yang digunakan adalah observasi tak terstruktur. Wawancara dilakukan untuk mendapatkan masukan dan ide dari para ahli. Sementara angket berupa lembar evaluasi digunakan untuk mengetahui penilaian dari para ahli dan responden. Teknik analisis data dilakukan dengan cara menyusun dan mengelompokan data, mendeskripsikan data dan mengambil kesimpulan. Analisis data dilakukan secara deskriptif yaitu uraian yang menjelaskan jawaban dari responden dalam angket, wawancara, dan hasil observasi. Hasil angket dianalisis dengan menggunakan ratting scale untuk mengetahui apakah game kuis yang dikembangkan perlu diperbaiki atau tidak. Langkah-langkah penghitungan skor berdasarkan rumus berikut (Sugiyono, 2009, p. 99): Langkah pertama, menghitung jumlah skor kriterium:

Skor tertinggi $\mathrm{x}$ Jumlah butir $\mathrm{x}$ Jumlah responden

Kemudian menghitung penilaian dan interpretasi responden:

Jumlah skor hasil pengumpulan data $\times 100 \%$ Jumlah skor kriterium 
Setiap butir skor kemudian dihitung dan dianalisis untuk mengevaluasi apakah suatu aspek dalam game kuis perlu diperbaiki atau tidak. Game kuis yang telah dirancang akan diperbaiki bila presentasi di bawah $60 \%$ atau kurang layak. Penilaian dan intrepretasi untuk mengetahui kelayakan mengacu pada Tabel 1.

Tabel 1. Presentasi penilaian dan interpretasi

\begin{tabular}{cc}
\hline Presentasi Penilaian & Interpretasi \\
\hline $81-100 \%$ & Sangat Layak \\
$61-80 \%$ & Layak \\
$41-60 \%$ & Cukup Layak \\
$21-40 \%$ & Kurang Layak \\
$0-20 \%$ & Tidak Layak \\
\hline
\end{tabular}

Sumber: Arikunto (2010, p. 44)

\section{Hasil dan Pembahasan}

Game kuis teori musik dikembangkan melalui beberapa tahap yaitu analysis, design, development, implementation, dan evaluation. Tahap analysis dibagi menjadi tiga yaitu analisis game kuis The Impossible Game Quiz, analisis pengguna, analisis instrumen evaluasi formatif dan analisis materi teori musik semester satu di STiMB. Data yang diperoleh dari analasisis game kuis adalah (1) Game kuis berisi pertanyaan dan jawaban dengan berbagai macam jebakan. The Impossible Game Quiz merupakan game kuis dengan tampilan sederhana yang berisi pertanyaan dan jawaban. Seperti namanya walaupun pertanyaannya sederhana, tetapi tidak mudah untuk menjawabnya. Banyak pertanyaan mengandung pertanyaan ganda, trik dan permainan kata-kata yang mengharuskan pemain berpikir di luar kebiasaan (think outside the box). Sepanjang permainan terdapat banyak jebakan yang memerlukan keterampilan dan refleks untuk menyelesaikannya; (2) Aturan main yang sederhana. Setiap level terdiri dari tiga nyawa yang akan berkurang saat pemain melakukan kesalahan. Jika pemain membuat kesalahan sampai tiga kali, maka game akan berakhir (game over). Ada juga pertanyaan yang dilengkapi timer mulai dari satu sampai 11 detik dengan gambar bomb yang akan meledak jika waktu untuk menjawab habis, yang berarti permainan langsung berakhir (game over); (3) Dibutuhkan konsentrasi dan daya ingat yang tinggi. Pemain harus benar-benar fokus dan peka pada pertanyaan di setiap level-nya, karena jika sampai melakukan kesalahan di level yang tinggi, pemain harus mengulang permainan dari level satu dan harus mengingat jawaban di setiap level yang sudah dimainkan. Hal yang menarik dari game ini adalah selain dibutuhkan kepekaan juga dibutuhkan daya ingat yang tinggi untuk dapat menyelesaikannya.

Data yang diperoleh dari analisis pengguna adalah (1) Umumnya mahasiswa STiMB merupakan lulusan SMA dimana mereka tidak pernah mempelajari teori musik sebelumnya, oleh sebab itu diperlukan banyak latihan untuk mengingat materi yang sudah dipelajari atau tidak kesulitan saat mempelajari materi selanjutnya; (2) Banyak mahasiswa mengisi waktu luangnya dengan bermain games, baik menggunakan smartphone, tablet, maupun laptop. Bermain game menjadi salah satu hiburan bagi mahasiswa saat menunggu jam perkuliahan.

Data yang diperoleh dari analisi instrumen evaluasi formatif di STiMB adalah kuis lisan, kuis tertulis dan worksheet. Kuis lisan dilakukan untuk mengetahui kemampuan mahasiswa dalam mengingat materi dengan cara berpikir cepat. Biasanya berupa pertanyaan singkat yang harus dijawab baik secara bergantian maupun berebutan. Setiap mahasiswa yang bisa menjawab dengan benar, akan mendapatkan point. Pertanyaan biasanya memiliki tema, misalnya tema "pitch pada satff dengan treble clef", contoh pertanyaannya adalah "nada apa yang terdapat pada garis ke tiga?" jawabannya adalah " $\mathrm{B}$ ". Berbeda dengan kuis tertulis dan worksheet. Keduanya digunakan untuk melatih keterampilan menulis simbol musik dan notasi musik, contohnya soal "menentukan letak nada", mahasiswa harus membuat clef pada staff kemudian menempatkan whole note sesuai soal (misalnya nada $G$, whole note ditempatkan pada garis ke dua). 
Data yang diperoleh dari analisi materi teori musik di STiMB adalah materi semester satu mencakup materi staff, note value, treble clef, bass clef, pitch, key signature, time signature, major scales, minor scales dan interval. Namun dalam penelitian ini, hanya beberapa materi saja yang akan digunakan, yaitu materi pada pokok bahasan pertemuan satu dan dua, antara lain staff, treble clef, bass clef, Grand Staff dan pitch. Materi tersebut merupakan materi paling dasar dan paling penting untuk mengajarkan cara membaca notasi musik.

Tahap Design mencakup jadwal perancangan, pembentukan tim, dan perancangan game kuis. (1) Jadwal perancangan dan revisi dimulai pada bulan Januari sampai dengan April 2014 dan tahap implementasi dilakukan pada bulan Mei 2014; (2) Tim terdiri dari penulis dan animator. Pembentukan tim perlu dilakukan mengingat bidang keahlian penulis adalah musik, sehingga penulis membutuhkan tim untuk dapat merealisasikan produk yang dirancang dengan menggunakan software Adobe Flash; (3) Perancangan game kuis diawali dengan menganalisis game kuis The Impossible Quis, dan menentukan materi teori musik. Analisis game kuis The Impossible Quis dilakukan untuk menentukan bentuk soal, jumlah soal dan materi teori musik yang akan digunakan. Mengingat bentuk tes yang digunakan adalah tes objektif, maka soal terdiri dari pilihan ganda dan isian singkat. Jumlah soal adalah 10 soal yang mencakup materi teori musik pertemuan satu dan dua dengan waktu untuk menyelesaikan sekitar 20 sampai 30 menit. Soal yang mengandung pertanyaan ganda, trik, permainan kata-kata dan jebakan tetap dipertahan namun tidak sesulit The Impossible Quiz. Hal ini sengaja dilakukan agar kegiatan evaluasi lebih terasa seperti permainan, mengingat kegiatan evaluasi biasanya identik dengan kecemasan.

Tahap Development diawali dengan perancangan flowchart, membuat daft soal, perancangan storyboard, perancangan desain interface dan layout, perancangan ani- masi dan terakhir audio. Perancangan flowchart pada dasarnya mengadaptasi game kuis The Impossible Quiz. Sementara pembuatan draft soal disesuaikan dengan materi teori musik semester satu yaitu materi pada pokok bahasan pertemuan satu dan dua yang dilengkapi dengan ear training. Draft soal kemudian disusun dalam storyboard yang terdiri dari 10 soal atau 10 level. Setiap level berisi satu soal dengan cara menyelesaikan yang berbeda-beda, antara lain menginput teks, memilih satu jawaban, memilih lebih dari satu jawaban, mencari jawaban tersembunyi, menebak bunyi (pitch), mencari jawaban dalam hitungan 10 detik dan mencoba keberuntungan. Selain cara menyelesaikan yang berbeda-beda, pada setiap level diisi dengan jebakan-jebakan untuk mengecoh pengguna, seperti slide tanpa pertanyaan, kotak untuk mengisi jawaban yang tidak berfungsi, atau mencari jawaban di sekitar slide.

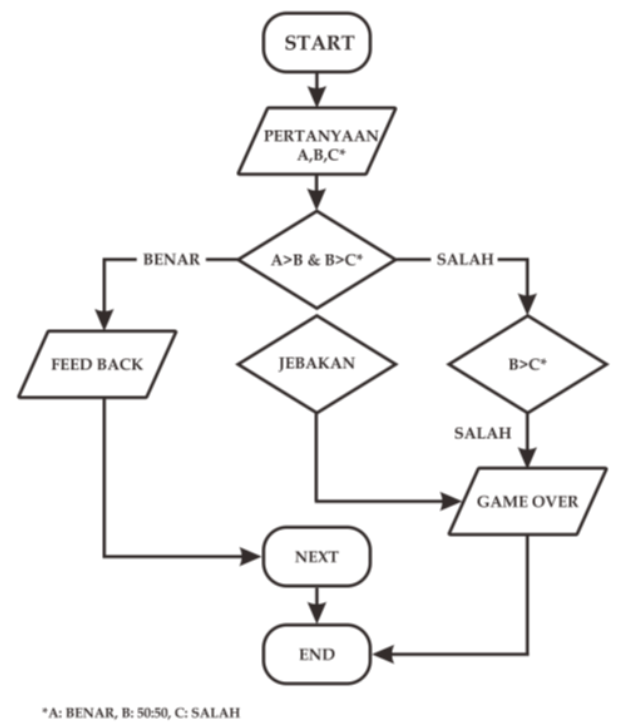

Gambar 2. Flowchart game kuis interaktif yang dikembangkan

Setelah merancang storyboard, tahap selanjutnya adalah membuat desain interface dan layout pada setiap level dengan menggunakan software CorelDraw X6. Untuk menghasilkan produk yang menarik penulis memilih warna-warna tersier yaitu 
Tabel 2. Garis besar storyboard

\begin{tabular}{|c|c|c|c|c|}
\hline Level & Materi & Soal & Gambar & Jawaban \\
\hline 1. & Staff & $\begin{array}{l}\text { Tidak ada pertanyaan. } \\
\text { Pemain harus fokus pada } \\
\text { gambar }\end{array}$ & $\begin{array}{l}\text { Lima buah garis dan kotak } \\
\text { untuk mengisi jawaban }\end{array}$ & $\begin{array}{l}\text { Ketik Staff pada kotak di } \\
\text { bawah gambar }\end{array}$ \\
\hline 2. & Clef & Bass Clef atau Treble Clef & $\begin{array}{l}\text { Gambar Treble Clef dan kotak } \\
\text { untuk jawaban }\end{array}$ & $\begin{array}{l}\text { Klik tulisan Treble Clef pa- } \\
\text { da pertanyaan }\end{array}$ \\
\hline 3. & Pitch & $\begin{array}{l}\text { Tidak ada pertanyaan. } \\
\text { Pemain harus fokus pada } \\
\text { gambar }\end{array}$ & $\begin{array}{l}\text { Gambar tuts piano dan wajah } \\
\text { karakter kartun }\end{array}$ & $\begin{array}{l}\text { Klik tuts piano nada F A } \\
\text { C E (wajah) }\end{array}$ \\
\hline 4. & Note Value & $\begin{array}{l}\text { Pilih salah satu } \\
\text { Pemain mencoba } \\
\text { keberuntungan }\end{array}$ & $\begin{array}{l}\text { Empat buah whole note dan } \\
\text { karakter kartun, salah sa- } \\
\text { tunya menangakap whole note }\end{array}$ & $\begin{array}{l}\text { Klik whole Note kedua } \\
\text { (warna hijau) }\end{array}$ \\
\hline 5. & $\begin{array}{l}\text { Pitch dan } \\
\text { Clef }\end{array}$ & $\begin{array}{l}\text { Mencari nada F. } \\
\text { Jawaban lebih dari satu }\end{array}$ & $\begin{array}{l}\text { Huruf F dan whole note pada } \\
\text { staff dengan treble clef dan } \\
\text { bass clef dalam kotak }\end{array}$ & Kotak 6, 11, 23, dan 25 \\
\hline 6. & $\begin{array}{l}\text { Pitch dan } \\
\text { Clef }\end{array}$ & Pilih nada G & $\begin{array}{l}\text { Gambar whole note pada staff } \\
\text { dengan treble clef dan bass clef } \\
\text { dalam kotak yang menun- } \\
\text { jukan nada D }\end{array}$ & $\begin{array}{l}\text { Menghapus tulisan pilih } \\
\text { dan mengganti huruf G } \\
\text { dengan D (kapital) } \\
\text { kemudian klik salah satu } \\
\text { kotak }\end{array}$ \\
\hline 7. & Pitch & $\begin{array}{l}\text { Lima pertanyaan dalam } \\
10 \text { detik. Klik, dengerin, } \\
\text { lalu pilih jawaban }\end{array}$ & $\begin{array}{l}\text { Speaker, treble clef, bass clef, } \\
\text { dan bomb }\end{array}$ & $\begin{array}{l}\text { Klik gambar treble clef } \\
\text { atau bass clef sesuai pitch: } \\
\text { treble, treble, bass, treble, } \\
\text { bass }\end{array}$ \\
\hline 8. & Pitch & Cari bunyi treble clef & $\begin{array}{l}\text { Kotak dengan angka } 1,2,3,4 \text {, } \\
\text { kotak untuk mengisi jawa- } \\
\text { ban, dan bomb }\end{array}$ & $\begin{array}{l}\text { Geser kotak, klik gambar } \\
\text { speaker di dalamnya lalu } \\
\text { isi kotak jawaban dengan } \\
\text { angka } 3\end{array}$ \\
\hline 9. & Pitch & $\begin{array}{l}\text { Low-High } \\
\text { Jawaban lebih dari satu }\end{array}$ & $\begin{array}{l}\text { Enam buah gambar speaker } \\
\text { dan tulisan pilih }\end{array}$ & $\begin{array}{l}\text { Klik pilih pada gambar } \\
\text { speaker no } 4,6,1,5,3 \text {, dan } \\
2\end{array}$ \\
\hline 10. & $\begin{array}{l}\text { Pitch dan } \\
\text { Clef }\end{array}$ & $\begin{array}{l}\text { Tidak ada pertanyaan. } \\
\text { Pemain harus fokus pada } \\
\text { gambar }\end{array}$ & $\begin{array}{l}\text { Gambar staff dengan treble } \\
\text { clef dan whole note yang } \\
\text { menunjukan nada } \mathrm{F} \text { (spasi } 1 \text { ) } \\
\text { tapi terdapat tanda tanya } \\
\text { pada spasi } 4\end{array}$ & $\begin{array}{l}\text { Klik huruf E (huruf } \\
\text { keempat pada tulisan LE- } \\
\text { VEL } 10\end{array}$ \\
\hline
\end{tabular}

penggabungan warna primer dan warna sekunder yang tidak terlalu mencolok.

Warna pada setiap level dibuat berbeda-beda untuk memberikan efek refresh, mengingat selama memainkan game pemain harus terus fokus pada layar monitor. Selain pemilihan warna yang tidak mencolok, pemilihan font sangat penting untuk memudahkan pemain saat membaca pertanyaan. Berdasarkan fungsinya, selain memilih font yang memiliki kejelasan huruf, pemilihan font yang menarik tidak kalah penting dalam proses ini, karena selain dapat memaksimalkan desain layout, juga dapat menarik perhatian pengguna untuk membaca teks. Adapun font yang digu- nakan antara lain Kidprint, Cheddar Salad BTN Qull, Nightclub BTM, dan Galeforce BTM. Setelah tahap ini selesai semua materi diserahkan kepada animator untuk dibuat animasi menggunakan Adobe Flash CS6. Tahap finishing adalah penambahan efek suara dan pembuatan backsound menggunakan Sibelius 7.2 dan Reason. Efek suara digunakan untuk menciptakan mood dan ilustrasi yang berkaitan dengan kejadian pada tampilan. Efek suara terdapat pada jawaban benar, jawaban salah, soal pitch, sumbu bomb yang menyala, bomb yang meledak, game over dan finish. Sementara Backsound dibuat dengan dua nuansa yang berbeda. Backsound dengan nuansa ceria digu- 
nakan untuk opening, dengan nada dasar $\mathrm{F}$ Major menggunakan instrumen string, woodwind, brass dan perkusi. Backsound dengan nuansa tegang digunakan saat game dimulai untuk mengganggu konsentrasi pengguna dengan nada dasar $\mathrm{E}$ minor, menggunakan instrumen piano, string, marimba dan clave.

Tahap Implementation dilakukan melalui tiga tahap. (1) Tahap satu dilakukan dengan hanya melibatkan tim. Pada tahap ini tim memastikan aplikasi berjalan sesuai dengan flowchart, dan menguji tingkat kesulitannya dengan memastikan setiap level dapat dijawab oleh responden dalam waktu 20 sampai 30 menit. Hal ini perlu dilalukan mengingat terdapat banyak jebakan yang membutuhkan kepekaan. Pada dasarnya aplikasi pada tahap ini berjalan sesuai dengan flowchart, hanya terdapat beberapa revisi antara lain perubahan layout, penambahan karakter kartun, revisi ilustrasi soal dan penambahan aturan; (a) Perubahan layout dilakukan karena terlihat terlalu polos dan kurang menarik. Perubahan yang dilakukan antara lain perubahan warna backgound dan font serta menambahkan judul game yaitu Just Music; (b) Penambahan karakter kartun. Tampilan yang hanya berisi soal terlihat terlalu monoton, solusinya penulis menciptakan karakter monster yang mewakili konten materi antara lain staff, treble clef, bass clef, dan grand staff. Staff diwakili monster berwarna biru yang mempunyai lima kaki. Pitch diwakili monster berwarna merah dengan kepala menyerupai quarter note. Treble clef diwakili monster warna kuning dengan telinga menyerupai kepala treble clef. Bass clef diwakili monster warna ungu, dengan telinga menyerupai kepala bass clef. Terakhir grand staff diwakili monster warna hijau dengan 10 buah kaki.

Monster-monster tersebut didisain dengan beberapa ekspresi yang bertujuan menghidupkan permainan dan menciptakan interaksi dengan pemain, dimana karakter tersebut akan menjadi objek penderita saat pemain melakukan kesalahan. Contohnya, saat pemain salah memi- lih jawaban, ekspresi monster yang ceria berubah menjadi sedih, atau saat bomb meledak monster berubah menjadi hitam (hangus); (c) Revisi ilustrasi soal pada level tiga, yaitu mengganti foto telur dengan gambar wajah monster. Pada level ini pemain diminta untuk menekan tuts piano sesuai dengan gambar. Awalnya gambar menggunakan foto telur, namun penggunaan foto tersebut dirasa tidak sesuai dengan konsep game. Revisi ilustrasi soal pada level tiga dapat dilihat pada Gambar 5; (d) Penambahan timer dalam bentuk bomb sebagai stimulan berpikir cepat dalam menjawab pertanyaan dan memberikan efek tegang; (2) Implementasi tahap dua dilakukan untuk memastikan kualitas produk setelah revisi. Pada tahap ini peneliti memastikan produk sudah siap untuk diimplementasikan ke tahap tiga; (3) Pada implementasi tahap tiga, produk diimplementasikan kepada para ahli dan responden. Implementasi para ahli didampingi oleh penulis, khusunya ahli media, karena tidak mengerti teori musik. Penulis memainkan game dan mencoba jawaban benar dan salah, ahli media mengamati, bertanya, memberi komentar dan menilai. Sementara ahli materi kurang memahami permainan namun setelah dijelaskan kemudian memainkan game sampai selesai.

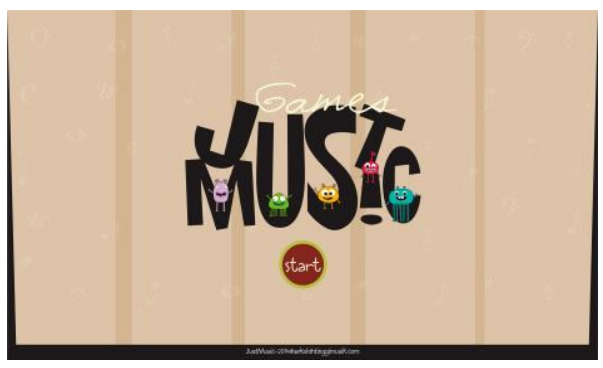

Gambar 3. Revisi halaman layout

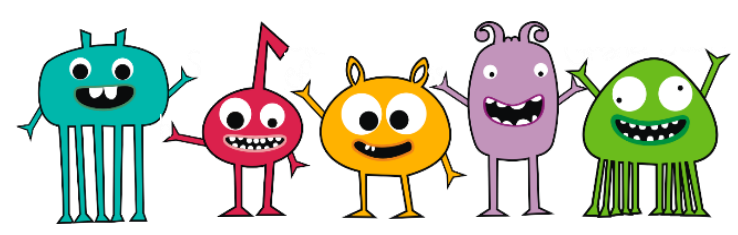

Gambar 4. Karakter kartun monster 
Berbeda dengan responden mahasiswa. Implementasi yang dilaksanakan di ruang komputer STiMB berjalan dengan lancar. Umumnya mahasiswa langsung bisa memainkan game setelah diberi tahu bahwa game diadaptasi dari game The Impossible Quiz, walaupun ada juga yang belum pernah memainkan game kuis tersebut tetapi bisa mengikuti alur permainan. Hal yang menarik pada saat mencoba game kuis, semua responden bertahan untuk menyelesaikan game yang terdiri dari 10 level karena penasaran dan ingin memenangkan game. Bahkan beberapa mahasiswa lain (selain responden) ikut mencoba game kuis ini.

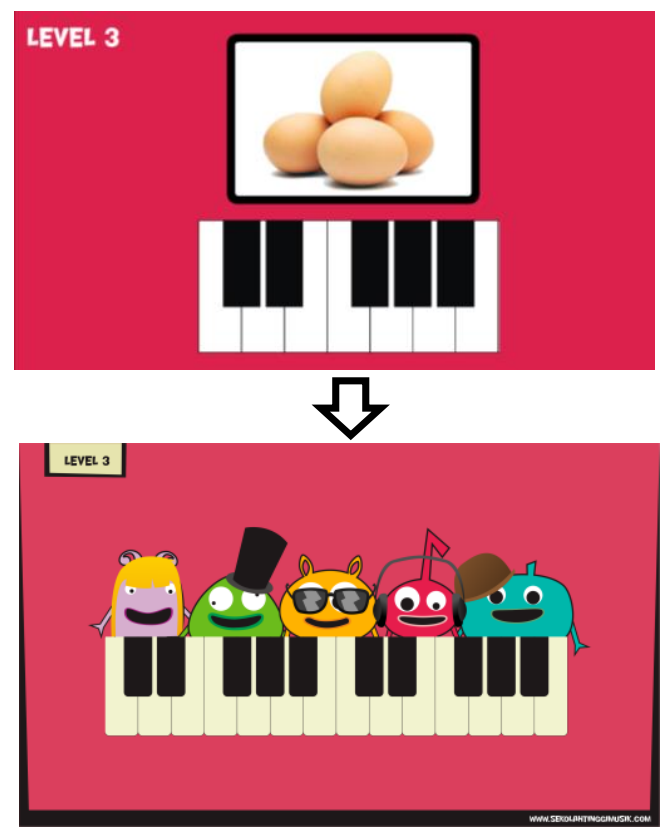

Gambar 5. Revisi ilustrasi soal

Untuk dapat memenangkan game ini pemain harus mencapai level tertinggi. Responden mulai berkompetisi untuk mencapai level tertinggi dengan waktu tercepat, sehingga suasana menjadi semakin ramai, beragam ekspresi muncul mulai dari tertawa, serius, bingung, sampai kesal. Ada yang saling menertawakan karena berkalikali game over, ada juga yang tampak serius memikirkan cara menjawabnya, dan beberapa berusaha menanyakan cara menjawab pada temannya, namun responden lain memilih untuk tidak memberi tahu caranya, karena merasa susah payah menemukannya.
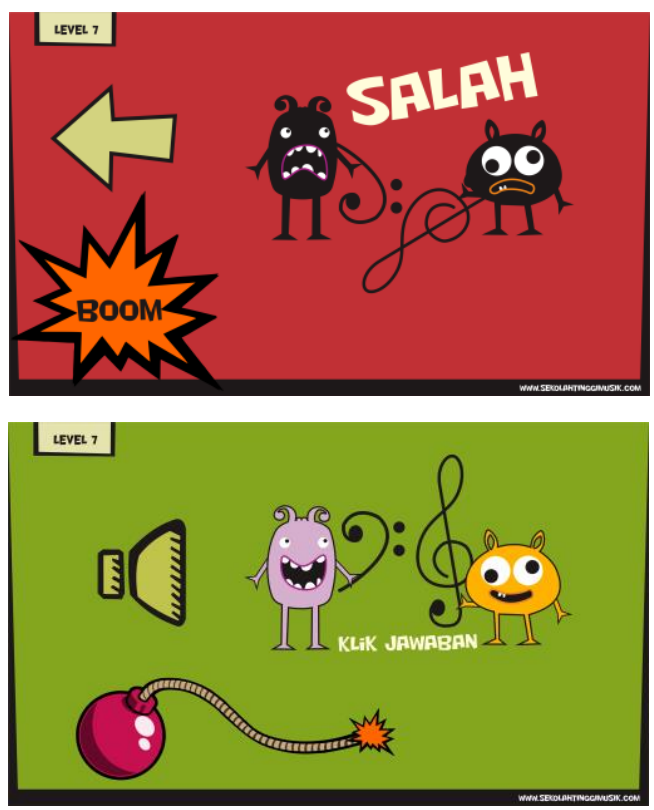

Gambar 6. Timer dalam bentuk bomb

Waktu tercepat menyelesaikan $g a$ me kuis adalah 20 menit dan paling lama adalah satu jam. Lamanya waktu menyelesaikan game disebabkan beberapa hal, antara lain terlalu lama memikirkan jawaban, kurang cepat mengambil keputusan untuk menjawab dan panik saat menentukan jawaban karena terpengaruh sumbu bomb yang semakin pendek. Umumnya responden gagal di level tujuh sehingga harus mengulang mulai dari level satu. Namun hal tersebut tidak membuat responden menyerah walaupun harus berusaha mengingat jawaban pada level sebelumnya.

Secara keseluruhan semua responden mengalami game over di level yang berbeda, namun semakin sering mengulang terlihat semakin cepat menjawab setiap pertanyaan. Hal ini sengaja dilakukan dimana fungsi jebakan dibuat agar pemain kalah dan harus mengulang dari awal, tujuannya untuk melatih daya ingat pemain mengingat evaluasi melalui game ini dikembangkan untuk mengukur ranah kognitif dengan menekankan aspek ingatan. Tanggapan dari responden umumnya mengatakan game-nya seru, nyebelin, bikin kesel, 
desainnya $l u c u$, ada juga yang mengatakan game-nya terlalu absurd.

Tahap evaluation dalam penelitian ini berdasarkan penilaian dari para ahli dan responden dalam bentuk angket yang meliputi aspek pembelajaran, aspek materi, aspek pemrograman atau pengoprasian game, dan aspek tampilan game. Hasil penilaian para ahli secara keseluruhan menunjukan interpretasi sangat layak. Penilaian tertinggi dari ahli materi adalah aspek materi yaitu sebesar $91,11 \%$ dan penilaian tertinggi dari ahli media adalah aspek tampilan game dengan presentasi sebesar 85,45\%. Ahli materi menyarankan untuk dikembangkan dengan konten materi yang lebih lengkap. Ahli media menyarankan untuk lebih memperhatikan pendapat dari sisi end user. Penilaian ahli materi dan ahli media dapat dilihat pada tabel 3 dan 4 .

Tabel 3. Penilain ahli materi

\begin{tabular}{clcc}
\hline No. & Aspek yang dinilai & Presentasi & Interpretasi \\
\hline 1. & Aspek Materi & 91,11 & $\begin{array}{c}\text { Sangat } \\
\text { Layak }\end{array}$ \\
2. & $\begin{array}{l}\text { Aspek } \\
\text { Pembelajaran }\end{array}$ & 75,55 & Layak \\
\hline
\end{tabular}

Tabel 4. Penilain ahli media

\begin{tabular}{|c|c|c|c|}
\hline No. & Aspek yang dinilai & Presentasi & Interpretasi \\
\hline 1. & $\begin{array}{l}\text { Aspek Tampilan } \\
\text { Game }\end{array}$ & 85,45 & $\begin{array}{l}\text { Sangat } \\
\text { Layak }\end{array}$ \\
\hline 2. & $\begin{array}{l}\text { Aspek } \\
\text { Pemrograman }\end{array}$ & 83,33 & $\begin{array}{l}\text { Sangat } \\
\text { Layak }\end{array}$ \\
\hline
\end{tabular}

Penilaian responden Mahasiswa STiMB melibatkan 33 orang mahasiswa semester dua dan semester empat dengan aspek penilaian meliputi aspek pembelajaran, aspek materi, aspek pemrograman dan aspek tampilan game. Hasil evaluasi responden mahasiswa menunjukan interpretasi sangat layak dengan presentasi tertinggi terdapat pada aspek tampilan game yaitu $84,85 \%$. Hasil penilaian responden mahasiswa dapat dilihat pada Tabel 5.

Penilaian dari para ahli dan seluruh responden mahasiswa kemudian diakumulasikan untuk mengetahui rerata penilaian secara keseluruhan, dengan cara menjumlahkan presentasi dari masing-masing as- pek kemudian dibagi jumlah aspek penilaian. Hasil rerata keseluruhan dari masingmasing aspek adalah sangat layak dengan presentasi tertinggi pada aspek materi sebesar $87,806 \%$.

Tabel 5. Penilaian responden mahasiswa

\begin{tabular}{cccc}
\hline No & Aspek yang dinilai & Presentasi & Interpretasi \\
\hline 1. & Aspek Pembelajaran & 83,79 & Sangat Layak \\
2. & Aspek Materi & 84,5 & Sangat Layak \\
3. & Aspek Pemrograman & 80,4 & Layak \\
4. & Aspek Tampilan Game & 84,85 & Sangat Layak \\
\hline
\end{tabular}

Tabel 6. Penilain rerata

\begin{tabular}{clcc}
\hline No & Aspek yang dinilai & Presentasi & Interpretasi \\
\hline 1. Aspek Pembelajaran & 79,67 & Layak \\
2. & Aspek Materi & 87,81 & Sangat Layak \\
3. Aspek Pemrograman & 81,87 & Sangat Layak \\
4. & Aspek Tampilan Game & 85,15 & Sangat Layak \\
\hline
\end{tabular}

\section{Simpulan}

Berdasarkan penelitian dan hasil analisis data dalam pengembangan game kuis interaktif teori musik dapat disimpulkan sebagai berikut: (1) Game kuis interaktif sebagai instrumen evaluasi formatif bentuk tes objektif dikembangkan dengan cara mengadaptasi game The Impossible Quis, menggunakan metode penelitian $R \mathcal{E} D$ model ADDIE melalui tahap analysis, design, development, implementation dan evaluation; (2) Hasil evaluasi dari ahli materi, ahli media dan responden mahasiswa STiMB, menunjukkan game kuis interaktif teori musik sangat layak diaplikasikan sebagai instrumen evaluasi formatif dengan rerata presentasi penilaian sebesar 83,62\%; (3) Ahli materi memberi penilaian sangat layak untuk aspek materi dengan presentasi $91,111 \%$ dan layak untuk aspek pembelajaran dengan presntasi 75,55\%; (4) Ahli media memberi penilaian sangat layak untuk aspek tampilan game dengan presentasi $85,45 \%$ dan sangat layak untuk aspek pemograman dengan presntasi 83,33\%; (5) Responden mahasiswa memberi penilaian sangat layak untuk aspek pembelajaran dengan presentasi sebesar $83,79 \%$, sangat layak untuk aspek materi dengan presentasi 
$84,50 \%$, layak untuk aspek pemrograman dengan presentasi sebesar $80,40 \%$ dan sangat layak untuk aspek pemrograman dengan presntasi $84,85 \%$; (6) Presentasi rerata masing-masing aspek menunjukan interpretasi sangat layak untuk aspek pembelajaran dengan presentasi $83,79 \%$, sangat layak untuk aspek materi dengan presentasi $84,50 \%$, layak untuk aspek pemrograman sebesar 80,4\% dan sangat layak untuk aspek tampilan game dengan presentasi $84,85 \%$; (7) Hasil implementasi membuktikan game kuis interaktif teori musik dapat menciptakan suasana evaluasi pembelajaran yang menyenangkan dan dapat memotivasi mahasiswa untuk mengukur kemampuannya dengan cara berpikir cepat dengan waktu penyelesaian paling cepat 20 menit.

\section{Daftar Pustaka}

Arikunto, S. (2010). Manajemen penelitian. Jakarta: Rineka Cipta.

Arikunto, S. (2015). Dasar-dasar evaluasi pendidikan. Jakarta: Bumi Aksara.

Aunurrahman, A. (2014). Belajar dan pembelajaran. Bandung: Alfabeta.

Branch, R. M. (2009). Instructional design: The ADDIE approach (vol. 722). New York: Springer Science+Business Media.

Gall, M. D., Borg, W. R., \& Gall, J. P. (2003). Educational research an introduction (7th edition). United States of America: Perason Education, Inc.

Jones, G. T. (1974). Music Theory: The Fundamental Concepts of Tonal Music Including Notation, Terminology, and Harmony. New York: A Barnes \& Noble Outline.

Rundell, M. (2007). Macmilian english dictionary for advanced learners (elt dictionaries series). London: Macmilian Education.

Setiawan, S. (2015). Kelas asik dengan games: 30 games untuk pembelajaran. Jakarta: PT. Gramedia.
Sugiyono, S. (2009). Metode penelitian kuantitatif, kualitatif, dan RED. Bandung: CV Alfabeta.

Sukardi, S. (2012). Evaluasi Pendidikan Prinsip E Operasionalnya. Jakarta: PT Bumi Aksara. 